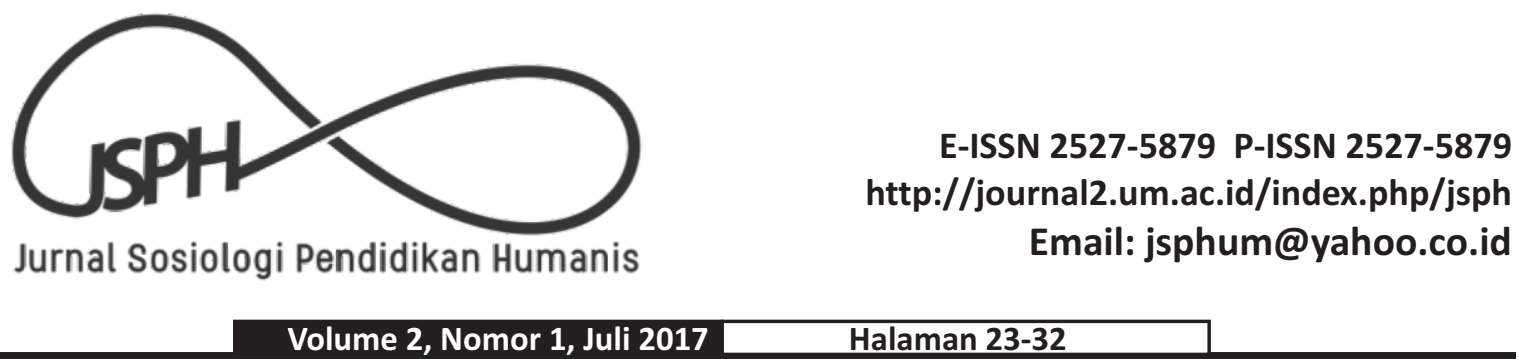

\title{
PEMANFAATAN HUTAN BERKELANJUTAN BERBASIS KELEMBAGAAN DI KAWASAN GUNUNG SASAK
}

\author{
Anisa Puspa Rani, Dwi Setiawan Chaniago \\ Program Studi Sosiologi Universitas Mataram \\ Email: Pusparani_anisa@yahoo.co.id, Setiawandwi279@yahoo.com
}

\begin{abstract}
Abstrak
Hutan Gunung Sasak merupakan kawasan Hutan Kemasyarakatan (HKm) seluas $\pm 477 \mathrm{Ha}$. Status HKm bertujuan untuk mempermudah proses rehabilitasi hutan dengan pemanfaatan ekonomis masyarakat di sekitar kawasan. Faktanya status HKm diartikan oleh masyarakat sebagai legitimasi pemanfaatan pribadi. Haltersebut berdampak pada kerusakan hutan baik secara ekologis maupun ekonomis. Penelitian ini bertujuan untuk mengembangkan model pemanfaatan HKm berbasis kelembagaan guna terwujudnya pemanfaatanhutan berkelanjutan dengan memperhatikan keseimbangan manfaat ekologis dan ekonomis dari fungsi hutan. Penelitian ini menggunakan teori strukturasi dan metode kualitatif. Hasil penelitian menunjukkan bahwa perlu upaya reorientasi pemanfaatan HKm Gunung Sasak dari semula bersifat individual ke kelembagaan, guna mencapai hal tersebut diperlukan dukungan multipihak dengan fokus intervensi meliputi pengembanganinfrastruktur, peningkatan kapasitas, serta pemantapan aspek jaringan ekonomi budidaya lebah madu pada Kelompok Madu Sari.
\end{abstract}

Kata Kunci: pemanfaatan; kelembagaan; infrastruktur; kapasitas; jejaring

\section{UTILIZATION OF INSTITUTIONAL-BASED SUSTAINABLE FORESTS IN THE AREA OF GUNUNG SASAK}

\begin{abstract}
Gunung Sasak Forestvis an area of Community Forest in (Hkm) of $477 \mathrm{Ha}$. The status of Hkm aims to facilitate the process of forest rehabilitation with the utilization economic comunity around the region . The status of Hkm is defined by the people as legitimacy of private use. It affects the forest damage both a kologically and economically . This study aims to develop an institutional-based Hkm utilization model for the realization of sustainable forest utilization by taking into consideration the balance of ecological and economic benefits of forest functions. This research draws on structuration theory and qualitative methods . The results of penelillions show that the need to reorient the utilization of Hkm Gunung Sasak from the beginning is individual he institutionalized, to achieve this required multistakeholder support with interventionist faculty including development of infrastucture, capacity building, as well as stabilizing aspects of building honeycomb culture network in Sari Madu Group.
\end{abstract}

Keywords: utilization; institutional; insfratucture; capacity; network 


\section{LATAR BELAKANG}

Gunung Sasak berdasarkan Surat Keputusan Menteri Kehutanan nomor 598/Menhut II/2009 merupakan kawasan hutan lindung. Kawasan hutan seluas 492 hektar tersebut secara ekologis dimanfaatkan oleh masyarakat lima desa yakni Desa Babusallam di bagian Utara, Desa Tempos di bagian Barat Laut hingga Barat (Kedua desa ini termasuk wilayah Kecamatan Gerung), Desa Giri Sasak berada di bagian Selatan, Desa Kuripan Selatan di bagian Tenggara dan Timur Gunung Sasak dan Desa Kuripan ada di sebelah Timur (ketiga desa ini masuk wilayah Kecamatan Kuripan).

Pada era 1980-an, kondisi Hutan Gunung Sasak masih sangat baik. Kawasan hutan masih ditumbuhi pepohonan rimbun seperti kelicung, sonokeling, jati, johar, akasia, enau dan berbagai jenis pepohonan lain. Tidak hanya vegetasi hutan yang masih lestari, lima mata air yang terdapat di kawasan Hutan Gunung Sasak pada periode yang sama juga masih terjaga dengan debit air yang baik. Kelestarian kondisi hutan saat itu sejalan dengan kondisi pemanfaatan hutan yang bersahaja. Masyarakat di sekitar kawasan Hutan Gunung Sasak hanya memanfaatkan ranting kayu untuk memenuhi kebutuhan kayu bakar. Pemanfaatan hutan berfokus pada pendayagunaan hasil hutan bukan kayu seperti madu dan bambu dan umbi-umbian.

Menariknya, pemanfaatan hasil hutan bukan kayu khususnya pemanfaatan lebah madu menjadi indikator kondisi kelestarian hutan. Berdasarkan hasil kajian Tim Penilaian Analisis Dampak Sosial dan Ekonomi Terhadap Kondisi Hutan Gunung Sasak bersama UNESCO, diketahui bahwa pada tahun 1980 hingga medio 1990an, hasil madu hutan Avis Dorsata sangat melimpah. Setiap setup atau kelongkongan dapat menghasilkan 4-5 botol $(1$ botol $=600 \mathrm{ml})$ madu lebah (Tim UNESCO, 2015). Hal tersebut tidak terlepas dari kondisi ketersediaan pakan lebah yang masih melimpah sejalan dengan lebatnya vegetasi hutan Hutan Gunung Sasak.

Kondisi krisis ekonomi di akhir 1990-an berdampak banyak terhadap kondisi pemanfaatan Hutan Gunung Sasak. Tekanan krisis ekonomi, peningkatan jumlah penduduk, hingga keterbatasan lapangan pekerjaan mendorong perubahan pemanfaatan kawasan Hutan Gunung Sasak . Kondisi tersebut diperparah dengan terjadinya kemarau panjang yang terjadi di Tahun 1998 yang berdampak pada merosotnya hasil pertanian. Menghadapi kondisi tersebut, adaptasi masyarakat mulai mengarah kepada eksplorasi kawasan Hutan Gunung Sasak. Masyarakat mulai melakukan pemanfaatan hutan dengan berbagai tujuan, seperti merambah hutan untuk menjual hasil kayu, hingga menanami di kawasan Hutan
Gunung Sasak dengan tanaman muda komoditas pertanian .

Aktivitas masyarakat dalam memanfaatkan hutan di tahun 2000-an semakin intens. Hal tersebut diperparah dengan aktivitas pembabatan kayu hutan secara massif oleh masyarakat. kesulitan dan tekanan ekonomi menjadi pendorong eksploitasi tidak terkendali terhadap kawasan hutan. Meskipun di periode yang sama usaha pemerintah untuk memulihkakan kondisi hutan melalui berbagai kegiatan reboisasi. Namun, keberadaan Kawasan Gunung Sasak telah terlanjur dianggap sebagai alternatif ekonomi dalam menambah pemasukan bagi masyarakat terus dilakukan dengan pemanfaatkan jangka pendek, yakni merambah hutan.

Rendahnya kesadaran akan kelestarian hutan berdampak pada kondisi Hutan Gunung Sasak yang semakin gundul. Kondisi tersebut disadari dan disikapi oleh masyarakat yang tergabung dalam kelompok tani hutan $(\mathrm{KTH})$ dengan mengajukan permohonan usulan perizinan Hutan Kemasyarakatan $(\mathrm{HKm})$ ke Bupati Lombok Barat. Tujuannya agar memberikan ruang bagi masyarakat untuk terlibat secara aktif dalam pengawasan dan pemantauan penggarap kegiatan pengelolaan dan perbaikan hutan. Melalui HKm, diharapkan masyarakat dapat terlibat dan bertanggungjawab dalam pengelolaan hutan serta dapat membawa kesejahteraan bagi masyarakat di sekitar kawasan hutan.

Berdasarkan Surat Keputusan Menteri Kehutanan Nomor 469/Menhut II/2014 tertanggal 12 Mei 2014, Kawasan Hutan Gunung Sasak berstatus sebagai Hutan Kemasyarakatan $(\mathrm{HKm})$ dengan areal kerja hutan seluas $\pm 477 \mathrm{Ha}$. Faktanya, status HKm Kawasan Gunung Sasak diinterpretasikan sebagai hak kelola dan pemanfaatan yang otonom oleh masyarakat. Status HKm, yang disikapi dengan pembagian sejumlah luasan lahan bagi setiap anggota kelompok tani hutan beralih fungsi menjadi kawasan garapan masyarakat dengan alasan peningkatan ekonomi . Dampaknya kawasan hutan semakin terdegradasi dalam berbagai bentuk pemanfaatan individual masyarakat seperti menanam tanaman muda, hingga kawasan ladang di beberapa titik lahan di kawasan Gunung Sasak.

Pemanfaatan $\mathrm{HKm}$ dengan pendekatan kelembagaan masih belum optimal. Hal tersebut disebabkan lemahnya mekanisme pengelolaan kelembagaan oleh pemanfaat HKm (Nandini, 2013: 46). Kondisi tersebut menjadi gambaran pemanfaatan HKm di kalangan masyarakat yang belum memiliki format pemanfaatan dan tata kelola HKm yang jelas. Berbagai indikasi menunjukkan pemanfataan $\mathrm{HKm}$ cenderung bers 
ifat individual. Pemanfaatan secara individual semakin mempertegas motif ekonomi dibanding prinsip kelestarian ekologis hutan. Akibatnya kerusakan dan degradasi lahan hutan menjadi konsekwensi logis dari pemanfaatan yang kurang bertanggungjawab tersebut. Pola pemanfaatan hutan yang berorientasi jangka pendek dengan menebang kayu hutan harus dibayar dengan efek jangka panjang berupa kerusakan hutan, vegetasi hutan yang menipis hingga potensi kekeringan dan banjir yang semakin besar.

Menariknya di kawasan Hutan Gunung Sasak sejak tahun 1984 terdapat komunitas masyarakat, yakni Kelompok Madu Sari yang melakukan pemanfaatan hutan di luar bidang pertanian (off farm employment) yakni melalui budidaya lebah madu. Off farm employment merupakan pekerjaan non-pertanian di lingkungan perdesaan yang dilakukan oleh keluarga atau kelompok masyarakat (Effendi, 1995:193). Kelompok ini sangat potensial sebagai jawaban bagi kebutuhan pemanfaatan $\mathrm{HKm}$ yang mengedepankan prinsip keberlanjutan dan keseimbangan aspek ekonomis dan ekologis hutan. Kelompok ini bisa terus mempertahankan eksistensinya sebab aktivitas budidaya lebah selama ini mampu menambah pemasukan ekonomi keluarga. Kendati saat ini Kelompok Madu Sari menjadi salah satu yang terdampak dari kerusakan Hutan Gunung Sasak. Sumber pakan lebah yang semakin berkurang akibat vegetasi hutan yang menipis berdampak pada produktivitas lebah madu yang semakin berkurang.

Berdasarkan kajian yang dilakukan UNESCO dan Universitas Mataram tahun 2015 tentang social impact assessment and livelihood analysis for strengthening local actions to deal with deforestation and land degradation in Lombok Barat, diketahui bahwa kerusakan Hutan Gunung Sasak disebabkan oleh rendahnya pemahaman masyarakat tentang pemanfaatan hutan berkelanjutan yang mempengaruhi kelestarian hutan dan kebermanfaatan ekonomis masyarakat di sekitar kawasan. Pemanfaatan HKm Gunung Sasak memerlukan integrasi antara berbagai program pemerintah dan stakeholders, dengan manfaat ekonomi bagi masyarakat guna mendorong partisipasi masyarakat dalam kegiatan reforestasi. Sedangkan penelitian ini berfokus pada upaya mendorong munculnya wahana kelembagaan dalam pemanfaatan hutan sebagai wadah partisipasi, dan pemberdayaan masyarakat di sekitar kawasan HKm. Wahana kelembagaan perlu dalam mengubah mindset masyarakat di sekitar kawasan agar terlibat secara aktif dalam upaya reboisasi dan pemeliharaan hutan serta mampu memperoleh manfaat ekonomis dengan memperhatikan kelestarian ekologis hutan. Adapun penelitian ini bertujuan untuk mengidentifikasi aspek-aspek pendukung fungsionalnya lembaga dalam pemanfaatan HKm, serta bentuk intervensi para pihak dalam menopang pemanfaatan hutan berkelanjutan berbasis kelembagaan.Salah satu faktor pendorong aktivitas pemanfataan hutan adalah desakan kebutuhan ekonomi.Desakan kebutuhan ekonomi pula yang memperkabur kebutuhan untuk mendapatkan keuntungan secara ekonomi dan aspek kelestarian lingkungan. Dengan motif keterpaksaan sebagai wujud adaptasi desakan kebutuhan hidup, Prinsip kelestarian lingkungan seringkali terabaikan dalam pemanfaatan kawasan hutan. Padahal aspek kelestarian lingkungan merupakan prasyarat utama dalam menjamin pembangunan lingkungan berkelanjutan (Amien, 2005: 151).

Pada masyarakat di sekitar kawasan HKm Gunung Sasak, motif keterpaksaan dalam kaitannya dengan perambahan hutan menjadi lumrah. Aktivitas pertanian padi dan palawija di kawasan perbukitan HKm masih ditemui dengan alasan mendapatkan tambahan pendapatan keluarga . Berdasarkan hasil observasi, sumber pendapatan dalam aktivitas ekonomi masyarakat di sekitar kawasan HKm terklasifikasi dalam dua bentuk, yakni pertama sumber pendapatan primer dari hasil pertanian padi, palawija,ernak, dan buah-buahan. Kedua, sumber pendapatan yang berasal dari di sektor off farm employment yakni dari hasil beternak, dan pemanfaatan hasil hutan bukan kayu seperti madu. Khususnya pendapatan yang bersumber dari budidaya madu, merupakan bidang kerja potensial untuk dikembangkan.

Khususnya pada masyarakat pemanfaat $\mathrm{HKm}$ di kawasan Dusun Batu Goleng, usaha budidaya lebah madu telah dilakukan secara berkelompok. Kendati demikian, kondisi kawasan hutan yang telah terdegradasi berdampak pada produktifitas hasil madu yang semakin menurun akibat terbatasnya kesediaan pakan yang ada di hutan. Agar bisa menjadi sumber pendapatan tambahan bagi masyarakat di sekitar kawasan, maka usaha budidaya lebah madu harus diiringi dengan upaya-upaya reboisasi hutan guna menjamin ketersediaan pakan lebah. Di samping itu, HKm dapat menjadi dasar bagi reorientasi bentuk pemanfaatan dari semula bersifat individual, menjadi berbasis kelembagaan. Pendekatan kelembagaan lokal tersebut berguna dalam upaya membentuk perilaku masyarakat yang partisipatif dalam kegiatan reboisasi hutan, peduli terhadap kelestarian hutan, serta mampu memanfaatkan hutan secara ekonomis sebagai sumber pendapatan tambahan tanpa melupakan prinsip kelestarian ekologis.

Degradasi hutan tidak hanya membawa dampak ekologis seperti menurunnya kuantitas 
dan kualitas vegetasi hutan. Lebih jauh, kondisi tersebut berdampak pada kondisi ekonomi masyarakat di sekitar kawasan. HKm yang pada hakekatnya bertujuan membuka ruang partisipasi masyarakat dalam mengelola dan memanfaatkan hutan justru beralih menjadi legitimasi bagi masyarakat memanfaatkan hutan untuk kebutuhan pribadi dan keluarga. Ketika pemahaman masyarakat tentang arti penting memanfaatkan hutan dengan memperhatikan prinsip kelestarian lingkungan tidak terbentuk, maka relasi yang terbangun antara masyarakat dan ekologi hutan merupakan relasi ketergantungan negatif, dimana masyarakat hanya memikirkan pemanfaatan hutan secara ekonomis jangka pendek, tanpa mempertimbangkan kelestarian lingkungan dalam jangka panjang. Disinilah peran negara diperlukan dalam mengakomodir nilai-nilai tradisional yang selama masih cenderung diabaikan oleh pemerintah (Suwarsono dan Alvin, 2013: 65). Hal tersebut penting dalam mereorientasi bentuk pemanfaatan hutan yang lebih ramah lingkungan.

Orientasi pemanfaatan ekonomis jangka pendek juga dapat dilihat partisipasi masyarakat yang cenderung pasif dalam berbagai program dan kegiatan reboisasi hutan. Meskipun banyak program dan kegiatan reboisasi yang masuk dalam menyikapi kondisi kerusakan lahan hutan, serta adanya legalitas atas keterlibatan masyarakat melalui $\mathrm{HKm}$, namun kesadaran dalam merawat hutan relatif rendah. Berbagai kegiatan reboisasi dan penanaman pohon di kawasan HKm gagal mendorong dan menumbuhkan kesadaran pentingnya menjaga kelestarian ekologis hutan. Sehingga tidak mengherankan, pasca ditanam berbagai bibit pohon dari program reboisasi tidak dijaga dan dirawat secara bertanggungjawab. Padahal pengelolaan sumberdaya potensial seperti kehutanan memerlukan peran aktif masyarakat (Soetomo, 2009:290).

Desakan kebutuhan ekonomi menjadi motif rendahnya minat dalam dalam partisipasi penanaman bibit pohon dan kayu-kayuan (Setiawan, 2016: 13) Nilai ekonomis pepohonan yang didapat dalam jangka waktu panjang tidak dapat membendung keinginan masyarakat mendayagunakan hak pengelolaan $\mathrm{HKm}$ dengan menanam tanaman-tanaman yang bernilai ekonomis namun tidak sesuai dengan spesifikasi tanaman sesuai status sebagai hutan lindung. Akibatnya berbagai kegiatan reboisasi menjadi tidak optimal. Sebab orientasi pemanfaatan lahan $\mathrm{HKm}$ secara individual cenderung lebih mendominasi dalam upaya mendapatkan manfaat ekonomis kawasan hutan.

Berdasarkan kondisi tersebut, sebagai kerangk a analisis penelitian ini menganggap perlu upaya pemanfaatan hutan berbasis kelembagaan. Hal tersebut bertujuan untuk mereduksi motif individual dalam pemanfaatan hutan $\mathrm{HKm}$, memudahkan pengintegrasian pemanfaatan dan pemeliharaan hutan, serta mendorong pemanfaatan ekonomis hutan yang bercorak off farm employment melalui pemanfaatan hasil hutan bukan kayu. Agar kegiatan ekonomis masyarakat di sekitar kawasan dapat berjalan seiringan dengan pemulihan degradasi lahan hutan.

Penelitian ini menggunakan prinsip strukturasi Anthony Giddens sebagai pisau analisis dalam memahami tindakan. Asumsi teoritis yang dipergunakan dalam kaitannya dengan perilaku individu dalam pemanfaatan HKm yakni pertama, perlunya wahana struktur yang mewadahi pembentukan tindakan individu melalui penanaman seperangkat nilai, pengetahuan, keterampilan dan standarisasi perbuatan. Kedua, individu tidak hanya dipandang sebagai aktor pasif dalam strukturnya, namun berperanpula sebagai aktor aktif, kreatif dan adaptif dalam menjalankan dan mempertahankan strukur. Ketiga, aktor mampu mengidentifikasi kebutuhan dan potensi yang dimiliki dan dituangkan dalam tindakan kolektif dalam sebuah struktur.

Dengan didasari tiga prinsip tersebut, maka penelitian ini secara operasional bertujuan untuk melihat transformasi individu sebagai pemanfaat HKm, yang tidak hanya menjadi objek namun sekaligus subjek kebijakan terkait upaya-upaya reforestasi dan pemanfaatan hutan. Melalui pendekatan kelembagaan, pemanfaatan $\mathrm{HKm}$ diharapkan dapat menghasilkan tiga aspek perubahan yakni pertama, sebagai wahana bagi peningkatan pengetahuan masyarakat dalam pemanfaatan hutan secara berkelanjutan baik secara ekologis dan ekonomis. Kedua, wahana bagi peningkatan keterampilan masyarakat dalam pemanfaatan HKm yang berorientasi pada pemanfaatan hasil hutan bukan kayu (khususnya budidaya madu hutan). Ketiga, wahana bagi reorientasi perilaku dan kebiasaan masyarakat yang semula memanfaatkan hutan secara individual menjadi kolektif di dalam kelembagaan.

Pada dasarnya pendekatan kelembagaan dalam perspektif strukturasi penting dalam membentuk tindakan individu. Pendekatan kelembagaan sebagai manifestasi struktur sangat penting mengingat individu dalam tindakannya dipengaruhi dorongan-dorongan eksternal, sekaligus menjadi agen bagi pembentuk dan penyempurna struktur yang adaptif terhadap kebutuhan dan potensi individu. Dengan kata lain, tindakan individu dapat dibentuk melalui sti 
mulus-stimulus dalam struktur yang sesuai dengan konsensus kebutuhan dan potensi bersama. Keberadaan lembaga akan sangat potensial dalam mengakomodir peran masyarakat dalam mengontrol kawasan hutan berdasarkan nilai sosial dan kearifan lokal yang berlaku. Sebab struktur merupakan media bagi aturan-aturan, serta pertemuan agen-agen dalam pemanfaatan sumberdaya (Usman, 2012:225).

Kelompok Madu Sari merupakan salah satu bentuk manifestasi struktur bagi masyarakat di sekitar kawasan Gunung Sasak. Potensi kelembagaan didalam Kelompok Madu Sari perlu dikembangkan mengingat bidang kegiatan pemanfaatan hutan yang bercorak off farm employment melalui budidaya madu sebagai hasil hutan bukan kayu, selaras dengan upaya menjaga kelestarian hutan. Sumber pakan lebah yang didapat melalui vegetasi hutan hanya akan didapat jika kondisi hutan terjaga. Kesadaran tersebut telah muncul namun belum terakomodir dalam aktivitas kelembagaan yang efektif. Hal tersebut disebabkan secara prinsipil kemampuan struktur kelembagaan Kelompok Madu Sari hanya akan fungsional ketika dijalankan oleh agen internal (anggota kelompok) dan perlu disinergikan dengan peran stakeholders seperti institusi, akademisi, LSM, pelaku ekonomi dan lain sebagainya.

\section{METODE PENELITIAN}

Penelitian yang dilakukan di Dusun Batu Goleng Desa Tempos, Kecamatan Gerung, Kabupaten Lombok Barat ini menggunakan metode kualitatif eksploratif dalam mendalami potensi pemanfaatan hutan secara berkelanjutan melalui pendekatan kelembagaan. Pengumpulan data dilakukan melalui Participatory Rural Appraisal (PRA), dan wawancara mendalam. PRA dilakukan pada 24 anggota Kelompok Madu Sari beserta pengurus. Teknik PRA dipergunakan untuk menghimpun informasi terkait sejarah desa, kecenderungan dan perubahan, kelender musim dan harian serta hubungan kelembagaan. Sedangkan teknik wawancara mendalam dilakukan terhadap tiga orang pengurus kelompok dan empat anggota kelompok yang bertujuan untuk menghimpun informasi terkait pemahaman, pengetahuan dan pemaknaan tindakan-tindakan terkait pemanfaatan hutan serta terhadap pentingnya aspek kelembagaan dalam pemanfaatan dan pemeliharaan hutan secara berkelanjutan.

\section{HASIL PENELITIAN \\ Pemanfaatan HKm; dari Individual Ke Kelembagaan}

Hutan kemasyarakatan $(\mathrm{HKm})$ merupakan be ntuk adaptasi pemerintah dalam menyikapi kondisi kerusakan hutan yang semakin massif. Lajunya proses deforestasi tidak terlepas dari dominannya motif ekonomi masyarakat dalam pemanfaatan hutan. Tidak dapat dipungkiri bahwa kawasan hutan sudah menjadi bagian dari kesatuan sosial ekonomi masyarakat yang telah dimanfaatkan dalam menambah sumber pendapatan. Tentu saja motif ekonomi tersebut ti dak dapat dieleminir namun harus dikelola secara bertanggungjawab. Untuk itu, kebijakan HKm muncul dalam upaya mengakomodir kebutuhan sekaligus meningkatkan partisipasi masyarakat dalam menjaga, merawat, dan mengelola hutan secara bertanggungjawab.

Kebijakan HKm merupakan impelementasi social forestry yang mendorong masyarakat di sekitar kawasan memiliki kapasitas dalam memanfaatkan dan mengelola hutan secara seimbang dan berkelanjutan baik secara ekonomi, ekologis, sosial dan budaya. Pada tataran implementatif, pemahaman (konsepsi) masyarakat tentang HKm masih belum jelas dan tumpang tindih. Hal tersebut sebagaimana ditemui pada masyarakat di kawasan Hutan Gunung Sasak. Masyarakat masih belum bisa membedakan pemanfaatan areal hutan (HKm) sebagai keseluruhan dengan mempertimbangkan daya dukung kelestarian ekosistem flora dan fauna, dengan areal perkebunan yang bebas dimanfaatakan untuk tumbuhan yang memiliki nilai ekonomis.

Kondisi pemanfaatan lahan $\mathrm{HKm}$ masih berorientasi individual. Akibatnya motif ekonomi dalam pemanfaatan hutan lebih dominan sebab dilakukan atas dasar kebutuhan untuk memenuhi ekonomi keluarga. Hasil pertanian di lahan sawah yang tidak menentu, dan keterbatasan lahan garapan di luar HKm turut mendorong aktivitas penanaman tanaman perkebunan dan palawija di areal HKm. Hal tersebut berdampak pada pemanfaatan areal hutan yang diperuntukkan pemanfaatan kawasan berbasis budidaya hasil hutan bukan kayu dan pemanfaatan jasa lingkungan belum teroptimalkan menjadi pemanfaatan menjadi pemanfatan HKm berbasis tanaman perkebunan.

Pemanfaatan $\mathrm{HKm}$ secara individual tidak terlepas dari misinterpretasi masyarakat tentang pengelolaan hutan. Pengelolaan individual seakan memberi ruang bagi masyarakat untuk membabat kayu hutan dengan maksud mendapatkan bantuan bibit pohon dan tanaman dari berbagai program pemerintah maupun swasta. Meskipun tidak disertai dengan kesadaran pemulihan daya dukung hutan melalui penanaman kembali (reboisasi) memakan waktu 
yang relatif panjang.

Hkm diasumsikan sebagai bentuk legitimasi pemanfaatan secara pribadi terhadap kawasan.Hal tersebut tentu menambah daftar panjang waktu pemulihan kawasan hutan yang terdegradasi akibat pemanfaatan yang kurang memperhatikan aspek ekologis kawasan. Kondisi ini menjadi indikasi rendahnya pemahaman masyarakat tentang arti penting pelestarian dan tata aturan dalam pemanfaatan kawasan $\mathrm{Hkm}$.

Pemanfaatan kawasan HKm Gunung Sasak bukan tanpa potensi. Keberadaan situs tempat peribadatan, sumber mata air, hingga keberadaan kelompok tani hutan dan kelompok budidaya lebah merupakan potensi yang belum teroptimalkan dalam pemanfaatan dan pengelolaan HKm. Khususnya kelompok budaya lebah madu sebagaimana yang dijalankan oleh Kelompok Madu Sari menjadi salah satu pemanfaat kawasan yang dapat dijadikan model pemanfaatan $\mathrm{HKm}$ yang memperhatikan prinsip keseimbangan dan keberlanjutan aspek ekologis dan ekonomi pemanfaatan hutan. Kelompok Madu Sari merupakan selah satu entitas yang terdampak akibat degradasi dan penurunan daya dukung ekosistem hutan. Penurunan produktivitas yang berujung penurunan pendapatan Kelompok Madu Sari tidak terlepas keterbatasan ketersediaan pakan lebah akibat penurunan kuantitas dan kualitas hutan.

Kesadaran menjaga kelestarian hutan, pemanfaatan berbasis kelembagaan, serta bidang pemanfaatan ekonomi yang bercorakoff farm employment melalui pemanfaatan hasil hutan bukan kayu merupakan potensi-potensi Kelompok Madu Sari yang perlu dioptimalkan dalam pengembangan model pemanfaatan $\mathrm{HKm}$ di kawasan Gunung Sasak. Intervensi terhadap Kelompok Madu Sari dapat menjadi momentum upaya reorientasi pemanfaatan kawasan $\mathrm{HKm}$ dari semula individual menjadi berbasis kelembagaan. Pendekatan kelembagaan itu penting dilakukan untuk mempermudah kontrol terhadap pemanfaatan kawasan $\mathrm{HKm}$ berbasis partisipasi masyarakat, serta menjadi wahana dalam memupuk kesadaran masyarakat tentang arti pentingnya pemanfaatan hutan dengan memperhatikan keseimbangan aspek ekonomi dan ekologis. Apalagi selama ini, berbagai proses rehabilitasi kawasan hutan kurang mendapatkan atensi masyarakat secara optimal mengingat lebih menonjolkan fungsi jangka panjang penanaman pohon saja. Dengan beralih pada upaya pemanfaatan $\mathrm{HKm}$ melalui budidaya lebah madu berbasis kelembagaan masyarakat, maka masyarakat akan semakin tertarik untuk melibatkan diri dalam berbagai kegiatan reboisasi dan rehabilitasi hutan sebab ada manfaat jangka pendek yang didapat yakni hasil budidaya lebah madu.

\section{Pemanfaatan Hutan Berkelanjutan Berbasis Kelembagaan Perlu dukungan Multipihak}

Hutan kemasyarakatan merupakan manifestasi distribusi hak pengelolaan kawasan hutan guna meningkatkan kesejahteraan masyarakat di sekitar kawasan sekaligus berperan aktif dalam pelestarian lingkungan. Program HKm didasari oleh amanat UndangUndang Nomor 41 tahun 1999 tentang Kehutanan, Peraturan Pemerintah Nomor 6 tahun 2007 tentang Tata Hutan dan Penyusunan Rencana Pengelolaan Hutan, serta Pemanfaatan Hutan, dan Peraturan Menteri Kehutanan Nomor P.37/Menhut-II/2007 tentang Hutan Kemasyarakatan. Keseluruhan produk regulasi tersebut merupakan kapasitas adaptif pemerintah dalam menyikapi tuntutan pemanfaatan kawasan hutan yang berbasis pemberdayaan dan peningkatan kesejahteraan masyarakat serta kelestarian ekologis hutan.

Pada prinsipnya pemanfaatan $\mathrm{HKm}$ perlu mengintegrasikan peningkatan ekonomi dan kesejahteraan masyarakat dengan usaha menjaga kelestarian hutan. Hal tersebut dapat dilakukan melalui pemberdayaan dan penguatan eksistensi kelembagaan pemanfaat HKm. Kelompok Madu Sari merupakan salah satu pemanfaat $\mathrm{HKm}$ berbasis kelembagaan yang representatif dalam upaya menjaga kelestarian hutan Gunung Sasak. Nilai ekonomis madu sebagai hasil hutan bukan kayu, serta kebutuhan pakan yang didapat melalui kelestarian lingkungan menjadi dasar bagi upaya pemanfaatan HKm yang mengutamakan keselarasan fungsi ekonomis dan ekologis kawasan bagi Kelompok Madu Sari.

Upaya mendorong Kelompok Madu Sari sebagai model percontohan dalam pengelolaan HKm pada dasarnya harus didukung oleh peran multipihak. Aspek legalitas yang memungkinkan bagi terciptanya sinergi dalam mendukung model pemanfaat HKm pada Kelompok Madu Sari sebagaimana pengejawantahan Peraturan Bupati Lombok Barat Nomor 22 tahun 2012 tentang Susunan Organisasi, Tata Kerja, Tugas, Hak, dan Kewenangan Institusi Multipihak. Peraturan Bupati tersebut, merupakan dasar payung hukum yang menjamin sinergisitas multipihak dalam mengatasi berbagai permasalahan dan mendorong pengembangan model percontohan pemanfaatan $\mathrm{HKm}$ dalam memanfaatkan potensi kawasan hutan.

Berdasarkan dinamika pemanfaatan kawasan HKm Gunung Sasak, terdapat kecenderungan terjadinya degradasi lahan khususnya di Desa Tempos Dusun Batu Goleng. Kerusakan hutan tersebut tidak terlepas dari aktivitas merambah hutan yang dalam perspektif masyarakat dilegimi 
tasi status HKm. Kondisi degradasi kawasan tidak terlepas dari kesalahpahaman masyarakat tentang makna pemanfaatan HKm. Daya dukung fungsi ekosistem hutan terdegradasi oleh tanamantanaman semusim dan aktivitas perambahan hutan guna mencari keuntungan tanpa memperhatikan kelestarian kawasan.

Kesalahpahaman dalam pemanfaatan $\mathrm{HKm}$ tersebut perlu diluruskan melalui kegiatan social learning process pengembangan kelembagaan berbasis komunitas sebagai percontohan pemanfaatan $\mathrm{HKm}$ dalam peningkatan ekonomi dan pemeliharaan ekosistem hutan, salah satu manfaat yang bisa dioptimalkan adalah hasil hutan bukan kayu berupa madu sebagaimana yang telah digeluti oleh Kelompok Madu Sari. Hanya saja Kelompok Madu Sari yang juga merupakan anggota kelompok tani hutan perlu didukung oleh banyak pihak guna mendorong terciptanya pemanfaatan hutan yang berkelanjutan berbasis kelembagaan oleh Kelompok Madu Sari perlu didukung multipihak. Untuk dapat menjadikan Kelompok Madu Sari sebagai model pemanfat kawasan HKm yang mengintegrasikan usaha pemeliharaan dan rehabilitasi hutan dengan peningkatan kesejahteraan ekonomi masyarakat perlu intervensi banyak pihak.

\section{Fokus Intervensi}

Kebijakan HKm tidak hanya berfokus pada fasilitasi legalitas izin pengelolaan dan pemanfaatan hutan. Lebih jauh, perlu upayaupaya pemberdayaan yang bersifat teknis terhadap masyarakat di sekitar kawasan untuk dapat mengelola dan memanfaatkan HKm sesuai prinsip kelestarian ekologis dan manfaat ekonomis. Pemberdayaan tersebut diperlukan untuk mewujudkan tata kelola pemanfaatan hutan yang baik, bertanggungjawab, dan berkelanjutan . Langkah awal yang dapat dilakukan yakni melalui reorientasi bentuk pemanfaatan dari semula bersifat individual menjadi berbasis kelembagaan. Pendekatan kelembagaan tersebut berguna dalam membangun pemahaman teknis tentang rehabilitasi hutan, pembibitan, budaya, pemanfaatan hasil hutan bukan kayu serta penguatan pemasaran dalam memperoleh manfaat ekonomis.

Berdasarkan hasil penelitian yang diperoleh, maka upaya reorientasi bentuk pemanfaatan $\mathrm{HKm}$ dari semula bersifat individual menuju kelembagaan dapat dilakukan melalui jalur strukturasi. Pendekatan strukturasi yang dimaksud adalah penguatan lembaga dalam pemanfaatan HKm dengan sasaran transformasi perilaku masyarakat dalam memanfaatkan hutan. Misinterpretasi masyarakat dalam memahami hak guna dalam pemanfaatan $\mathrm{HKm}$ perlu dilurusk an dengan model pemberdayaan lembaga masyar akat lokal dengan menanamkan seperangkat nilai tata aturan pengetahuan hingga keterampilan yan g relevan dalam upaya memanfaatkan hutan seca ra ekonomis serta lestari secara ekologis. Dalam model pemberdayaan berbasis lembaga lokal ters ebut, tentu penting memposisikan masyarakat tid ak sebagai penyebab masalah, melainkan bagian dari potensi penyelesaian masalah.

Motif ekonomi dalam pemanfaatan sumberdaya hutan tentu menjadi perhatian utama. Hal tersebut selaras dengan tujuan HKm dalam mensejahterakan masyarakat di sekitar kawasan hutan. Hanya saja prinsip keberlanjutan harus ditanamkan pada masyarakat. Agar hutan bisa menjadi sumber pendapatan keluarga, maka kelestarian hutan perlu dijaga. Untuk itu, upaya pemanfaatan perlu didorong ke pemanfaatan hasil hutan bukan kayu. Upaya reorientasi perilaku masyarakat tentu bukan usaha mudah. Namun dengan melihat potensi kelembagaan masyarakat seperti Kelompok Madu Sari, peluang untuk merubah perilaku masyarakat di sekitar kawasan HKm masih sangat terbuka lebar untuk dilakukan.

Hkm pada dasarnya merupakan bentuk kebijakan pemerintah berkarakter strukturasi dalam mengubah perilaku individu. HKm merupakan salah satu cara pemerintah dalam membuka ruang partisipasi bagi masyarakat. Status masyarakat sebagai pemanfaat $\mathrm{HKm}$ merupakan bentuk penyerahan hak kelola bagi masyarakat dalam mengelola dan memanfaatkan hutan. Distribusi peran dari pemerintah kepada kelompok masyarakat perlu dikelakukan dalam wahana kelembagaan yang membentuk agensiagensi yang menjalankan kegiatan pemeliharaan, pengelolaan, dan pemanfaatan hutan. Pendekatan kelembagaan tentu tidak hanya sebatas upaya menumbuhkan wahana kelembagaan yang lebih jauh, lembaga kemasyarakatan dalam pemanfaatan $\mathrm{HKm}$ perlu memiliki instrument yang terukur dalam merubah perilaku dan kebiasaan masyarakat dalam memanfaatkan hutan.

Intervensi perubahan perilaku pemanfaatan $\mathrm{HKm}$ menggunakan pendekatan strukturasi melalui kelembagaan lokal masyarakat dapat dilakukan dalam tiga aspek, yakni pertama Kelompok Madu Sari sebagai lembaga lokal pemanfaat $\mathrm{HKm}$ menjadi wahana peningkatan pengetahuan dan kesadaran masyarakat untuk dapat memanfaatkan hutan secara berkelanjutan baik secara ekologis maupun ekonomis. Berdasarkan temuan penelitian, wujudnya berupa edukasi jenis tanaman yang diperbolehka n ditanam di kawasan HKm, pemanfaatan jenis hasil hutan bukan kayu (HHBK), pengolahan produkHHBK, pengembangan kapasitas keorga 
nisasian anggota, edukasi dan sosialisasi proses reforestasi, serta pemilihan jenis tanaman yang bisa dipergunakan sebagai sumber pakan untuk usaha budidaya lebah madu.

Kedua, Kelompok Madu Sari menjadi wahana kelembagaan dalam peningkatan keterampilan masyarakat dalam memanfaatkan hasil hutan bukan kayu, yakni melalui budidaya lebah madu berbagai produk olahan madu, peningkatan keterampilan pemasaran produk, mengembangkan budidaya lebah trigona (selain apis dorsata), peningkatan keterampilan dalam memelihara dan merehabilitasi hutan, serta upaya lainnya yang berguna dalam meningkatkan pemanfaatan hutan baik secara ekonomis maupun secara ekologis. Ketiga, melalu wahana kelembagaan Kelompok Madu Sari, perilaku dan kebiasaan masyarakat telah tereorientasi, baik dari cara pemanfaatan $\mathrm{HKm}$ yang sebelumya bersifat individual menjadi kelembagaan, terbentuknya kebiasaan pemanfaatan hutan secara bertanggungjawab dengan memperhatikan keseimbangan ekosistem, serta pemanfaatan HHBK (budidaya lebah madu) sebagai upaya peningkatan pendapatan keluarga yang sejalan dengan upaya melestarikan ekologi hutan.

Optimalisasi pemanfaatan hutan berbasis kelembagaan diperlukan dalam membangun kolektivitas masyarakat dalam menjaga kelestarian hutan sekaligus dapat memperoleh manfaat ekonomis dari hutan. Pada Kelompok Madu Sari , kolektivitas dalam pemanfaatan $\mathrm{HKm}$ dalam kaitannya dengan pengelolaan dan pemanfaatan hutan dalam budidaya lebah telah terbentuk. Hanya saja untuk menjadikan Kelompok Madu Sari sebagai model percontohan dalam tata kelola $\mathrm{HKm}$ berbasis kelembagaan di Kabupaten Lombok Barat masih memerlukan intervensi pada tiga fokus aspek yang meliputi pengembangan infrastruktur, peningkatan kapasitas, serta pemantapan aspek jaringan ekonomi budidaya lebah madu.

Pengembangan infrastruktur dalam kelembagaan Kelompok Madu Sari meliputi dua komponen utama, yakni infrastruktur yang berkaitan dengan pengelolaan hutan, dan infrastruktur pengembangan usaha budidaya lebah madu. Infrastruktur pengelolaan hutan berguna dalam memfasilitasi sarana-prasarana bagi masyarakat dalam menjaga dan merawat hutan. Tidak dapat dipungkiri, berbagai program rehabilitasi hutan melalui penanaman pohon seringkali terhenti pada proses penanaman bibit pohon. Selanjutnya upaya-upaya pemeliharaan pohon pasca-tanam sangat minim dan berjalan alamiah. Belum lagi jika bibit pohon yang ditanam tidak sesuai dengan kebutuhan ekonomis masyarakat, sehingga atensi masyarakat dalam merawat dan menjaga pohon tersebut menjadi ren dah.

Pengembangan infrastruktur usaha budidaya lebah madu perlu ditingkatkan. Faktor infrastruktur yang selama ini telah diupayakan secara swadaya oleh Kelompok Madu Sari perlu diperkuat dengan berbagai bantuan pemerintah. Selama ini Kelompok Madu Sari telah mendapatkan bantuan berupa Setup, kloni lebah, peralatan peyaringan dan pengemasan madu. Kendati demikian, berkurangnya ketersediaan pakan harus disertai dengan efektifitas pemanfaatan madu dengan pengembangan diversifikasi produk madu lebah. Hanya saja untuk upaya diversifikasi produk madu tersebut masih terkendala kurangnya infrastruktur usaha. Diversifikasi produk yang belum bisa dikembangkan oleh Kelompok Madu Sari seperti pengolahan lilin dari sarang lebah dan permen madu.

Upaya mendorong berkembangnya kelembagaan Kelompok Madu Sari perlu ditopang peningkatan kapasitas. Terdapat dua aspek penting kapasitas perlu dikembangkan oleh Kelompok Madu Sari yakni pengembangan kapasitas personal anggota Kelompok Madu Sari terkait kelembagaan, serta pengembangan kapasitas komunitas sebagai basis pengembangan modal sosial dan membangun kolektifitas dalam membangun dan mengelola $\mathrm{Hkm}$. Kondisi kapasitas personal anggota Kelom pok Madu Sari ditandai dengan rendahnya tingkat pendidikan formal, pemahaman praktis pemanfaatan $\mathrm{HKm}$ yang berorientasi secara ekonomis semata, serta kesadaran dan partisipasi anggota kelompok yang cenderung terbentuk melalui mobilisasi ketua. Kondisi tersebut harus mendapatkan intervensi pemberdayaan yang bersifat partisipatif.

Intervensi pengembangan kapasitas sangat potensial untuk dilakukan mengingat adanya komitmen anggota Kelompok Madu Sari dalam menjaga kelestarian hutan. Umumnya anggota memiliki pemahaman atas konsekwensi rusaknya hutan terhadap aktivitas ekonomi budidaya lebah. Kelestarian hutan merupakan kebutuhan bagi ketersediaan pakan lebah dalam menunjang kelangsungan usaha budidaya lebah. Untuk itu Kelompok Madu Sari memiliki aturanaturan tidak tertulis yang mengikat anggota kelompok agar terlibat aktif dalam dalam upaya rehabilitasi dan menjaga kelestarian hutan. Anggota yang melanggar konsensus bersama akan dikenai sanksi sosial yakni tidak dilibatkan dalam berbagai kegiatan kelompok.

Upaya yang dilakukan dalam peningkatan kapasitas anggota kelompok selama ini belum teroganisir secara baik. Meskipun berbagai pihak seperti pemerintah daerah, swasta, dan akademisi telah melakukan berbagai kegiatan pemberdayaa 
n dalam peningkatan kapasitas. Namun kegiatan pelatihan yang dilakukan belum berfokus pada pengembangan tata kelola pemanfaatan $\mathrm{HKm}$. Padahal ada banyak aspek yang harus dikembangkan meliputi pengembangan kapasitas teknis tentang kelembagaan, tata kelola pemanfaatan $\mathrm{HKm}$, hingga pengembangan bidang usaha agar kelompok Madu Sari. Berkaca pada berbagai teknik peningkatan kapasitas yang telah dilakukan, perlu adanya upaya transformasi teknik peningkatan kapasitas Kelompok Madu Sari dari pola pemberdayaan bersama masyarakat (Empowerment with Community) menjadi pola pemberdayaan oleh masyarakat (Empowerment by Community) dalam upaya mendorong pemanfaat $\mathrm{HKm}$ yang berbasis kelembagaan.

Bidang intervensi ketiga dalam mendukung pemanfaatan $\mathrm{HKm}$ agar membawa dampak ekonomis terhadap kesejahteraan masyarakat di sekitar kawasan adalah pemantapan aspek jaringan ekonomi budidaya lebah madu . Rendahnya partisipasi masyarakat dalam rehabilitasi hutan tidak terlepas dari minimnya manfaat jangka pendek yang didapat dari kegiatan tersebut. Meskipun pada Kelompok Madu Sari kesadaran anggota dalam menjaga kelestarian hutan telah terbentuk. Namun upaya pemantapan jaringan ekonomi baik dari segi permodalan dan pemasaran komoditas perlu dikembangkan. intervensi pengembangan jaringan permodalan perlu dilakukan untuk memperkuat modal dan memperbesar skala usaha. Selama ini dalam usaha budidadaya lebah madu Kelompok Madu Sari belum tersentuh akses permodalan. Hal tersebut disebabkan usaha yang dijalankan belum memenuhi prayarat akses modal di perbankan (tidak bankable). Selain itu, lembaga keuangan makro Badan Usaha Milik Desa berupa Usaha Ekonomi Desa-Simpan Pinjam (UED-SP) juga belum menyentuh kebutuhan permodalan Kelompok Madu Sari. Adapun pemenuhan modal yang selama ini didapat cenderung didapat melalui usaha swadaya maupun melalui pinjaman koperasi keliling.

Pengembangan jaringan pemasaran juga perlu mendapatkan intervensi pemerintah maupun stakeholder lain. Model pemasaran yang dijalankan Kelompok Madu Sari masih terbatas dan bersifat konvensional. Pemerintah daerah melalui Dinas Kehutanan dan Bakorluh telah berusaha membantu memperbaiki kemasan untuk menambah daya tarik komoditas. Bahkan secara aktif mempromosikan produk dengan membuka jaringan pemasaran madu kepada wisatawan baik dalam maupun luar negeri. Namun komoditas madu yang dihasilkan belum sepenuhnya marketable sebab terbatasnya produktivitas yang dihasilkan akibat ketersediaan pakan lebah yang a da di kawasan Hutan Gunung Sasak belum sepenu hnya pulih.

\section{PENUTUP}

Kebijakan Pemerintah dalam memfasilitasi masyarakat dalam pengelolaan dan pemanfaatan hutan melalui $\mathrm{HKm}$ bertujuan untuk memberi ruang seluas-luasnya bagi usaha mencapai kesejahteraan masyarakat. Adanya legalitas $\mathrm{HKm}$ perlu disertai dengan keadaran masyarakat untuk dapat memanfaatkan hutan secara bertanggungjawab dengan memperhatikan keseimbangan kelestarian lingkungan dan manfaat ekonomis. Pendekatan kelembagaan merupakan salah satu alternatif yang dapat dikembangkan pengimpelementasian social forestry yang berbasis kolektifitas komunitas masyarakat disekitar kawasan H Km. Salah satu bentuk pemanfaatan potensial yang dikembangkan dalam model percontohan pengelolaan HKm sebagaimana ditemui pada Kelompok Madu Sari. Hanya saja dalam untuk mengoptimalkan pemanfaatan HKm berbasis kelembagaan pada Kelompok Madu Sari diperlukan upaya dan dukungan multipihak dengan fokus intervensi meliputi pengembangan infrastruktur, peningkatan kapasitas, serta pemantapan aspek jaringan ekonomi budidaya lebah madu pada Kelompok Madu Sari.

\section{DAFTAR RUJUKAN}

Afrizal. (2015). Metode Penelitian Kualitatif. Jakarta: Raja Grafindo

Amien, Mappadjantji. (2005). Kemandirian Lokal. Jakarta: Gramedia.

Blaikie, Norman. (2000). Designing Social Research. UK: Polity Press

Giddens, Anthoni. (2003). The Constitution of Society: Teori Strukturasi Untuk Analisis Sosial. Yogyakarta: Pedati.

ITTO. (2001). Mewujudkan Pengelolaan Hutan Lestari yang ada di Indonesia: Hutan Tana man berguna untuk Penciptaan Sumber D aya yang ada .Seri 3 Hasil Laporan untuk Misi Teknis ITTO Untuk Indonesia. Biro KLN Departemen Kehutanan.

Laeyendecker L. (1991). Tata, Perubahan dan Ke timpangan, Suatu Pengantar Sejarah Sosio logi. Jakarta:Gramedia

Nandini, Ryke. (2013).Evaluasi Pengelolaan Hut an Kemsyarakatan (Hkm) pada Hutan Pro duksi dan Hutan Lindung DiPulau Lombo k.Laporan ini tidak diterbitkan. Mataram

Peraturan Bupati Lombok Barat Nomor 22 tahun 2012 membahas tentang Susunan Organis asi, Tata Kerja,Tugas, Hak, dan juga Kew enangan Institusi Multipihak. (2012). Lom bok Barat

Peraturan Mentri Kehutanan No.P.37/Menhut-II/ 
2007 Tentang Hutan Kemasyarakatan. (2007). Jakarta:Kemenhut

Silverman, David. (2005). Doing Qualitative Res earch. London: Sage Publications.

Soetomo. (2009). Pembangunan Masyarakat. Yogyakarta: Pustaka Pelajar.

Suwarsono \& Alvin. (2000). Perubahan Sosial dan Pembangunan. Jakarta: LP3ES

Sztompka, Pieter. (2004). Sosiologi Perubahan So sial. Terjemahan Oleh Alimandan. (2012). Yogyakarta: Prenada.

Tim UNESCO. (2015). Laporan ParticipatoryRur al Appraisal Tim UNESCO Tentang Dam pak Sosial Ekonomi Kerusakan Lahan untu k Hutan Gunung Sasak.Laporan ini tidak di terbitkan. Mataram: Universitas Mataram Tim UNESCO. (2015). Laporan Penelitian Penil aian Analisis Dampak Sosial dan Ekonomi Terhadap Kondisi Hutan Gunung Sasak. Laporan ini tidak diterbitkan. Universitas Andalas, Universitas Gadjah Mada, dan Universitas Mataram

Usman, Sunyoto. (2012). Pembangunan dan Pem berdayaan Masyarakat. Yogyakarta: Pusta ka Pelajar

Usman, Sunyoto. (2004). Jalan Terjal Perubahan Sosial. Yogyakarta: CIReD.

Zubaedi. (2007). Wacana Pembangunan Alternat if. Yogyakarta: Ar-Ruzz Media Group. 